Revista Eletrônica Geografar, Curitiba, v. 2, Resumos do VI Seminário Interno de Pós-Graduação em Geografia, p. 34-34. Junho/2007

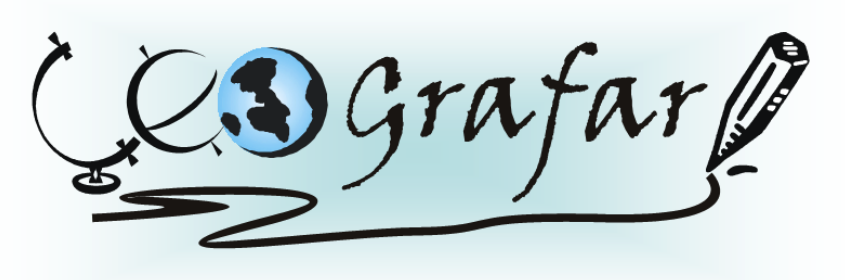

Revista Eletrônica do Programa de Pós-Graduação em Geografia - UFPR

\title{
CARTOGRAFIA DE BIÓTOPOS APLICADA AO BAIRRO SANTA FELICIDADE (CURITIBA/PR): UMA FERRAMENTA DE PLANEJAMENTO DA PAISAGEM EM ÁREAS URBANIZADAS
}

\author{
HELIO FILENO PUGLIELLI NETO ${ }^{1}$
}

A intensificação dos níveis de urbanização e o crescimento das aglomerações urbanas colocam novos problemas e questões aos estudos da paisagem, à medida que as cidades tornam-se cada vez mais o habitat dominante do Homem atual. O Planejamento da Paisagem destaca-se neste horizonte, como um meio de proporcionar uma possível conciliação das potencialidades da paisagem com as necessidades do desenvolvimento e da ocupação do espaço urbano. Inclui-se neste domínio a preocupação com a conservação da Natureza no ambiente urbano, não só de importância ecológica em relação à biodiversidade, mas também em relação à manutenção de uma diversidade de paisagens como um elemento de enriquecimento da vivência urbana. Dentro desta abordagem, o mapeamento de biótopos coloca-se como uma base conceitual adaptada à abordagem tanto das paisagens naturais quanto das alteradas em diversos graus pela ação antrópica, não obstante ainda sejam poucos, relativamente à importância do tema, os estudos nestes termos realizados no Brasil. Fundamentada nos princípios do Planejamento da Paisagem, a pesquisa visa identificar e mapear os diversos biótopos atualmente presentes no bairro de Santa Felicidade, em Curitiba/PR, e suas eventuais extensões nas regiões limítrofes, dando especial ênfase aos fragmentos florestais que ainda ocupam consideráveis áreas na citada região. Os procedimentos envolvidos abrangem a caracterização estrutural e biológica de tais fragmentos, permitindo a valoração dos biótopos, e a análise da sua espacialização geográfica em escalas compatíveis, por meio de trabalhos em campo e da análise de fotografias aéreas e cartas temáticas. Os resultados da pesquisa poderão eventualmente embasar proposições de medidas de conservação da Natureza na área em questão e a possíveis adequações no zoneamento dos usos do solo, colaborando na melhoria da qualidade ambiental.

Palavras-chave: biótopos, ecologia urbana, planejamento da paisagem

${ }^{1}$ Mestrando em Geografia - UFPR - email: hneto3@gmail.com Orientador:JOÃO CARLOS NUCCI 